infants suspected of having reflux are given trimethoprim from birth and then investigated by cystourethrography.

We still have much to learn about prenatal ultrasonography, and the need for interdisciplinary collaboration is great. ${ }^{1}$ Patients' interests are probably best served by prompt antenatal referral of suspected fetal uropathy to a regional specialist centre, even though in many instances delivery will be undertaken in the local hospital.

Professor of Paediatric Nephrology,

RICHARD H R WHITE

Children's Hospital,

Ladywood,

Birmingham B16 8ET

1 Watson AR, Readett D, Nelson CS, Kapila L, Mayell MJ. Dilemmas associated with antenatally detected urinary tract abnormalities. Arch Dis Child 1988;63:719-22.

2 Gunn TR, Mora JD, Pease P. Outcome after antenatal diagnosis of upper urinary tract dilatation by ultrasonography. Arch Dis Child 1988;63:1240-3.

3 Glick PL, Harrison MR, Noall RA, Villa RL. Correction of congenital hydronephrosis in utero III early mid-trimester ureteral obstruction produces renal dysplasia. F Pediatr Surg 1983;18:681-7.

4 Glick PL, Harrison MR, Adzick NS, Noall RA, Villa RL. Correction of congenital hydronephrosis in utero IV: in utero decompression prevents renal dysplasia. F Pediatr Surg 1984;19:649-57.
5 Bernstein J. Renal hypoplasia and dysplasia. In: Edelmann CM Jr, ed. Pediatric kidney disease. Vol II. Boston: Little, Brown, 1978:541-57.

6 Thomas IT, Smith DW. Oligohydramnios, cause of the nonrenal features of Potter's syndrome, including pulmonary hypoplasia. I Pediatr 1974;84:811.4

7 Golbus MS, Harrison MR, Filly RA, Callen PW, Katz M. In utero treatment of urinary tract obstruction. Am J Obstet Gynecol 1982;142:383-8.

8 McFadyen IR. Obstruction of the fetal urinary tract: a role for intervention in utero? $\mathrm{Br}$ Med $\mathfrak{f}$ 1984;288:459-62.

9 Nicolaides $\mathrm{KH}$, Rodeck $\mathrm{CH}$, Gosden $\mathrm{CM}$. Rapid karyotyping in non-lethal fetal malformations Lancet 1986;i:284-7.

10 Harrison MR, Golbus MS, Filly RA, et al. Fetal surgery for congenital hydronephrosis. $N$ Engl f Med 1982;306:591-3.

11 Manning FA, Harrison MR, Rodeck C. Report of the International Fetal Surgery Registry. Catheter shunts for fetal hydronephrosis and hydrocephalus. N Engl f Med 1986;315:336-47.

12 Elder JS, Duckett JW Jr, Snyder HM. Intervention for fetal obstructive uropathy: has it been effective? Lancet 1987;ii:1007-10.

13 Thomas DFM, Gordon AC. Management of prenatally diagnosed uropathies. Arch Dis Child 1989;64:58-63.

14 Hutson JM, McNay MB, MacKenzie JR, Whittle MJ, Young DG, Raine PAM. Antenatal diagnosis of surgical disorders by ultrasonography. Lancet 1985; ; $621-3$.

15 Glick PL. Harrison MR, Golbus MS, et al. Management of the fetus with congenital hydronephrosis II: prognostic criteria and selection for treatment. F Pediatr Surg 1985;20:376-87.

16 Clarke NW, Gough DCS, Cohen SJ. Neonatal urological ultrasound: diagnostic inaccuracies and pitfalls. Arch Dis Child 1989;64:578-80

17 Birmingham Reflux Study Group. Prospective trial of operative versus non-operative treatment of severe vesicoureteric reflux in children: five years' observation. $B r M e d ~ \mathcal{F} 1987 ; 295: 237-41$.

18 Ransley PG, Risdon RA. Reflux nephropathy: effect of anti-microbial therapy on the evolution of early pyelonephritic scar. Kidney Int 1981;20:733-42.

\title{
Mechanical ventilation at home
}

\author{
May save life and improve its quality
}

For many years a few patients have used mechanical ventilation successfully at home. ${ }^{1}$ Now that the importance of nocturnal hypoventilation in causing diurnal respiratory failure and cor pulmonale is known, ${ }^{2-5}$ together with the importance of respiratory muscle fatigue, ${ }^{67}$ there is renewed interest in mechanical ventilation. This has been encouraged by the introduction of the simple and efficient technique of intermittent positive pressure ventilation delivered noninvasively through a nasal mask. ${ }^{89}$

Patients who survive with severe, unremitting weakness of the respiratory muscles require continuous mechanical ventilation, usually with intermittent positive pressure through a permanent tracheostomy. Non-invasive techniques, which avoid the complications and constraints of a permanent tracheostomy, are preferred for those who require ventilatory assistance only at night. Intermittent negative pressure can be applied to the thoracoabdominal wall with a tank ventilator, cuirass, or airtight jacket and frame or positive pressure can be delivered to the airway through a mouthpiece or well fitting nasal mask.

The indications for domiciliary ventilation include central sleep apnoea; respiratory or cardiorespiratory failure secondary to skeletal deformity; static or only slowly progressive neuromuscular disease; and healed pulmonary tuberculosis treated surgically with resultant pulmonary restriction. ${ }^{10-13}$ Excellent results have been reported in all these. The value of home ventilation in managing progressive neuromuscular disease, particularly muscular dystrophy, is being explored. It may prove preferable to long term domiciliary oxygen treatment. A trial of home ventilation against long term domiciliary oxygen treatment in patients with chronic obstructive pulmonary disease is being sponsored by the Department of Health.

About 500 patients in the United Kingdom are using mechanical ventilation at home. ${ }^{14}$ Proportionately higher figures have been reported from Europe and the United States and probably some patients here would benefit, but they either have not been identified or have no service available. ${ }^{15} 16$ Improvements are likely to come from concentrating the facilities in regional centres with arrangements for funding the capital cost of the equipment and its maintenance and supervision. ${ }^{17}{ }^{18}$ Home ventilation saves lives in some patients with otherwise fatal cardiorespiratory failure, reduces the need for repeated hospital admission, and improves the quality of life by relieving daytime disability. ${ }^{19}{ }^{20}$ It is high time that this valuable service is organised on a national basis.

M A BRANTHWAITE

Consultant Physician,

Brompton Hospital,

London SW3 6HP

1 Kinnear WJM, Schneerson JM. Assisted ventilation at home: is it worth considering? Br f Dis Chest 1985;79:313-51

2 Catterall JR, Douglas NJ, Calverley PMA, et al. Transient hypoxemia during sleep in chronic obstructive pulmonary disease is not a sleep apnea syndrome. Am Rev Respir Dis 1983;128:24-9.

Sawicka EH, Branthwaite MA. Respiration during sleep in kyphoscoliosis. Thorax 1987;42:801-8.

4 Midgren B, Petersson K, Hansson L, Eriksson L, Airikkala P, Elmqvist D. Nocturnal hypoxaemia in severe scoliosis. Br, Hansson L, Eriksson L, A

in severe scoliosis. Brf Dis Chest 1988;82:226-36.
Smith PEM, Calverley PMA, Edwards RHT. Hypoxemia during sleep in Duchenne muscular mith PEM, Calverley PMA, Edwards RHT. H
dystrophy. Am Rev Respir Dis 1988;137:884-8.

dystrophy. Am Rev Respir Dis 1988;137:884-8.
6 Rochester DF, Arora NS. Respiratory muscle failure. Med Clin North Am 1983;67:573-97.

6 Rochester DF, Arora NS. Respiratory muscle failure. Med Clin North Am 1983;67:573-97.
7 Cropp A, DiMarco AF. Effects of intermittent negative pressure ventilation on respiratory muscle function in patients with severe chronic obstructive pulmonary disease. Am Rev Respir Dis 1987;135:1056-61

8 Ellis ER, Bye PTB, Bruderer JW, Sullivan CE. Treatment of respiratory failure during sleep in patients with neuromuscular disease. Am Rev Respir Dis 1987;135:148-52.

Carroll N, Branthwaite MA. Intermittent positive pressure ventilation by nasal mask: technique and applications. Intensive Care Med 1988;14:115-7.

10 Goldstein RS, Molotiu N, Skrastins R, et al. Reversal of sleep-induced hypoventilation and chronic respiratory failure by nocturnal negative pressure ventilation in patients with restrictive ventilatory impairment. Am Rev Respir Dis 1987;135:1049-55.

11 Sawicka EH, Branthwaite MA, Spencer GT. Respiratory failure after thoracoplasty: treatment by intermittent negative pressure ventilation. Thorax 1983;38:433-5.

12 Kerby GR, Mayer LS, Pingleton SK. Nocturnal positive pressure ventilation via nasal mask. Am Rev Respir Dis 1987;135:738-40.

13 Carroll N, Branthwaite MA. Control of nocturnal hypoventilation by nasal intermittent positive pressure ventilation. Thorax 1988;43:349-53.

14 Schneerson J. Disorders of ventilation. Oxford: Blackwell Scientific Publications, 1988.

15 ANTADIR [French National Association for the Domiciliary Treatment of Respiratory Insuffciency] Report. Bull Eur Physiopathol Respir 1986;22 (suppl 9).

16 Make BJ, Gilmartin ME. Rehabilitation and home care for ventilator-assisted individuals. Clin Chest Med 1986;7:679-91.

17 Goldberg AI. Home care for life-supported persons: is a national approach the answer? Chest 1986;90:744-8.

18 O'Donohue WJ Jr, Giovannoni RM, Goldberg AI, et al. Long term mechanical ventilation: guidelines for management in the home and at alternate community sites. Chest 1986;90(suppl): $1-37$.

19 Robert D, Gerard $M$, Leger $P$, et al. Domiciliary ventilation by tracheostomy for chronic respiratory failure. Revue Française des Maladies Respiratoires 1983;11:923-36.

20 Sawicka EH, Loh L, Branthwaite MA. Domiciliary ventilatory support: an analysis of outcome. Thorax 1988;43:31-5. 